\title{
INFLUENCE OF MATERNAL FACTORS ON FOETAL MALNUTRITION USING CAN SCORE ASSESSMENT- A TERTIARY CARE CENTRE EXPERIENCE
}

\author{
Ajay Mohan Varahala', Naga Kalyani Pathuri², Suresh Kumar Chidugulla ${ }^{3}$ \\ ${ }^{1}$ Associate Professor, Department of Paediatrics, Niloufer Hospital, Hyderabad, Telangana. \\ ${ }^{2}$ Assistant Professor, Department of Pathology, Osmania Medical College, Hyderabad, Telangana. \\ 3 Professor, Department of Paediatrics, Niloufer Hospital, Hyderabad, Telangana.
}

\begin{abstract}
BACKGROUND
ABSTRACT

Potential conditions that predispose babies to being small at birth are quite common in tropical practice. Several factors may predispose to SGA delivery. ${ }^{1}$ Maternal factors known to contribute to foetal malnutrition (FM) include biological factors, nutritional factors, brief interpregnancy intervals, low socio-economic class, poor education, medical and obstetric problems.

The main aim of the study was to assess whether maternal factors are influencing the nutritional status of foetus.
\end{abstract}

\section{MATERIALS AND METHODS}

The present study is undertaken at Niloufer Hospital for Children, Osmania Medical College, a tertiary paediatric care centre to assess the nutritional status of new born at birth. The study included a total of 125 neonates born to mothers who have completed 38 weeks of gestational age. Neonates with major congenital malformations were excluded from the study. CAN Score was calculated for all the babies. Maternal data of the mothers of these babies is recorded in detail.

\section{RESULTS}

The association between the nutritional status and each factor of maternal data is checked with both CAN Score cut-off points at $\leq 24$ and $\leq 21.63 .34 \%$ of the babies born to primi para mothers had foetal malnutrition and $73.33 \%$ of the babies born to mothers with low haemoglobin levels had FM with CAN Score cut-off of $\leq 24$.

\section{CONCLUSION}

Maternal factors and her nutritional status play a major role in the birth size of a baby. Maternal biological factors which may influence FM include parity, maternal haemoglobin and mode of delivery.

\section{KEYWORDS}

CAN Score, Foetal Malnourishment, Maternal Factors, Maternal Haemoglobin, Neonate, Parity.

HOW TO CITE THIS ARTICLE: Varahala AM, Pathuri NK, Chidugulla SK. Influence of maternal factors on foetal malnutrition using CAN score assessment- a tertiary care centre experience. J. Evolution Med. Dent. Sci. 2018;7(12):1434-1439, DOI: $10.14260 /$ jemds/2018/326

\section{BACKGROUND}

About 20 million babies are born per year with birth weights less than 2500 grams worldwide and $30 \%-40 \%$ of these infants are born at term gestation and therefore are SGA and it was observed that at least one-half of these babies are foetally malnourished. ${ }^{2}$ With foetal and maternal nutritional therapy starting at mid pregnancy, FM might be prevented or corrected and millions of babies worldwide would be spared a break future and have a better chance for a normal productive life as competitive citizens. ${ }^{3}$ Foetal malnutrition is common and a potentially serious problem during the perinatal period and for the later growth and development of the child. Unless looked for in the neonate, foetal malnutrition can be detected readily in the neonates by simple clinical examination. ${ }^{3}$

'Financial or Other Competing Interest': None.

Submission 26-02-2018, Peer Review 10-03-2018,

Acceptance 12-03-2018, Published 19-03-2018.

Corresponding Author:

Dr. Naga Kalyani Pathuri,

H. No. 16-3-989/c,

Near Police Hospital,

Malakpet, Hyderabad-500024,

Telangana, India.

E-mail: kalyani.pathuri@gmail.com

DOI: $10.14260 /$ jemds/2018/326
The most rapid period of normal foetal growth is in the 24 weeks, i.e. between 12 and 36 weeks of gestation. Between 32 and 36 weeks, the rate of foetal weight gain reaches its peak at 200 - 225 grams per week and declines thereafter. ${ }^{3}$ During a 40-week gestational period, the normal growing human foetus accumulates about 400 grams of protein beginning at conception and 475 grams of fat (most of it in last 8 weeks) as well as 2700 grams of water and contained minerals. In disagreement with Naismith's hypothesis the foetus is not a parasite, it only extracts about $2 \%$ to $4 \%$ of nutrients reaching to it from the placenta, $96 \%$ to $98 \%$ being returned to placenta and maternal circulation. It can be underfed or over nourished depending on extraction and nutrient composition of umbilical cord blood and the flow rate and capacity to utilise the extracted nutrients.

\section{Effects of Under-Nutrition in Pregnancy Undernutrition in Early Pregnancy}

The early embryo is selective in its use of nutrients. Hyperglycaemia delays embryonic growth and is implicated in the early pregnancy. This effect is in contrast to the accelerated growth associated with hyperglycaemia in the late pregnancy. Hypoglycaemia which is difficult to record in the late pregnancy, may also retard the growth and development of the embryo. Thus, both hyper- and hypoglycaemia in early embryogenesis may be associated with low birth weight. 4 


\section{Undernutrition in Mid Pregnancy}

The placenta grows faster than the foetus in the mid pregnancy. Although, severe maternal undernutrition restricts growth of both foetus and placenta, mild undernutrition may lead to increased placental size but not foetal size. Similarly, mild hypoxaemia in high altitude region and anaemia increases the placental size. This placental growth may be an adaptation to sustain nutritional supply from the mother. ${ }^{4}$

\section{Undernutrition in Late Pregnancy}

In late gestation maternal undernutrition promptly slows down foetal growth and alters the metabolic interaction between foetus and placenta. Foetal growth is sacrificed to maintain placental function. The placenta reduces its consumption of oxygen and glucose, while maintaining a large output of lactate. The lactate is also partly derived from amino acids of the foetal origin due to which foetus may be wasted and thin at birth. Maternal smoking profoundly hampers foetal growth, weight, height and head circumference. The effects of smoking increase with age. This cause is treatable and adverse effects of smoking on foetus can be nullified, if the mother is abstained from smoking during the latter half of pregnancy. ${ }^{4}$

\section{CAN Score}

It is Clinical Assessment of Nutritional Status and the Score is called CAN Score. ${ }^{3}$ It is a simple, rapid and quantifiable examination to differentiate SGA and FM babies. Clinical assessment of nutritional status was developed as a systematised extension of the observations of McLean and Usher and Scott and Usher. Nine superficial readily detected signs of malnutrition are checked in this scoring. They are Hair, Cheeks, Chin and Neck, Skin of forearm, Skin of thighs and legs, back in the scapular and interscapular region, buttocks, chest and abdomen. Each of the signs is rated from 4 (Best, No Evidence of Malnutrition) to 1 (Worst, Definite Evidence of FM). The total rating ranges from 36, which is the highest and 9 as the lowest. Assessment should be done in newborns within 24 to 48 hours after birth. The scores 24 or less than 24 are taken as clinical evidence of foetal malnutrition, which must have occurred in uteri.

\section{Aim of Study}

The main objective of study is to assess the nutritional status of new born at birth using CAN Score and to assess the possible relation with the maternal factors.

This study is taken because the term foetal malnutrition even though is being used as a synonym of SGA for all these days, has received a new concept of thinking that it is entirely different from SGA. ${ }^{3}$ Its diagnosis is very important, because recently it has been thought that it is the foetal malnutrition that accounts for the morbidity and mortality of many SGA babies and its incidence can effectively be decreased by efficient nutritional rehabilitation, good regular antenatal care and early nutritional supplementation in early new-born period.
}

\section{MATERIALS AND METHODS}

The new-born babies are selected from Niloufer Hospital located in Hyderabad. This is a tertiary referral centre and is a recognised institute for undergraduate and postgraduate studies. The Institute is affiliated to Osmania Medical College, Hyderabad. The hospital gets patients of all socio-economic status.

The present study is a cross-sectional study conducted on 125 singleton healthy neonates born to mothers with fullterm gestation of more than 38 weeks. Taking the prevalence of foetal malnourishment as $30 \%$ as per study conducted by UNICEF in the year $2004^{5}$ with a confidence interval of $95 \%$ and absolute precision as $8 \%$, the sample size calculated was 131 using the formula $\mathrm{N}=(\mathrm{z})^{\wedge} 2 \times \mathrm{pq} / \mathrm{l}^{\wedge} 2$. Systematic random sampling was used to select the new-born babies. Every 4 th new-born was selected into the study until the sample size was reached. Out of 131 , only 125 mothers have given consent for carrying out the study. Hence, the results of only 125 babies are included in the study. Chi-square test was done for testing statistical significance. $P$ value $<0.05$ was taken as significant. Chi-square with Yates correction was used wherever necessary. All the babies are thoroughly assessed for their health status. The gestational age of these babies is assessed through Expanded Ballard scoring system. Anthropometric data and the parameters of CAN Score of all these babies were collected within 48 hours after their birth. CAN Score is applied on all babies and a score is given to each baby.

The babies are classified under FM, if their score is less than or equal to $24(\leq 24)$. Neonates with scoring of $\leq 24$ were again re-examined and the score was confirmed. By using growth percentile charts, the neonates were classified as appropriate for dates (AFD) and small for dates (SFD). Care was taken to avoid any subjective variation in the collection of the data of each baby.

Similarly, maternal data was collected according to a protocol. Each maternal data is divided into 2 possible groups (Factors 1 and 2)-

1. Age of Mother

1. With age less than or equal to 20 years.

2. With age more than 20 years.

2. Parity

1. Primi Para- $1^{\text {st }}$ delivery.

2. More than one delivery. Multiple is not included separately, as the same is less.

3. Antenatal check-ups (ANC)

1. Regular- With ANC 4 or more times.

2. Irregular- With ANC less than 4 times.

4. Drug Intake: Drug intake means any drug other than vitamins and iron supplements.

1. Received.

2. Not received.

5. Associated Diseases: Means any maternal disease or complications of pregnancy.

1. With disease.

2. Without disease.

6. Mode of delivery.

1. Spontaneous vaginal or forceps or vacuum deliveries.

2. LSCS deliveries. 
7. Socio-Economic status: Based on per capital income per month.
1. Less than Rs. 300 .
2. More than Rs. 300.

8. Literacy of mother.
1. Illiterate.
2. Functional Literate, i.e. education upto $5^{\text {th }}$ class.
3. Education from $6^{\text {th }}$ to $10^{\text {th }}$ class.
4. College Education.

9. Addiction and Habits: Like smoking, alcohol intake or drug addiction.

10. Birth Spacing.
1. With spacing less than 2 years.
2. With spacing equal to or more than 2 years.

11. Mother's weight.
1. With Weight less than or equal to $40 \mathrm{kgs}$.

2. With Weight more than 40 kgs.

12. Mother's Weight gain during pregnancy.
1. Less than 9 kgs.
2. Equal to or more than $9 \mathrm{kgs}$.

13. Mother's haemoglobin concentration $6,7,8$
1. Haemoglobin less than $9 \mathrm{gm} \%$.
2. Haemoglobin equal to or more than $9 \mathrm{gm} \%$.

The association between FM and factors like drug intake during pregnancy and maternal habits could not be made, because in this sample not even a single mother has received any drug nor has any significant habit or addictions. Among 15 mothers 12 mothers had PIH, one mother had suffered from chicken pox in the last trimester of pregnancy, one mother had APH before delivery and one mother was found to be HIV positive.

\section{RESULTS}

CAN Score assessment was done for all 125 babies. The results are tabulated as shown in Table No. 1. On observing the table, maximum number of foetally malnourished babies are found between CAN Scores of 21 and 24. To avoid a large proportion of neonates in community being categorised as abnormal, the CAN Score value of $\leq 21$ can be taken as cutoff. ${ }^{9}$

\begin{tabular}{|c|c|}
\hline CAN Score & No. of Babies \\
\hline 15 & 1 \\
\hline 16 & 1 \\
\hline
\end{tabular}

\begin{tabular}{|c|c|}
\hline 17 & 0 \\
\hline 18 & 1 \\
\hline 19 & 3 \\
\hline 20 & 6 \\
\hline 21 & 5 \\
\hline 22 & 16 \\
\hline 23 & 16 \\
\hline 24 & 13 \\
\hline 25 & 17 \\
\hline 26 & 11 \\
\hline 27 & 12 \\
\hline 28 & 5 \\
\hline 29 & 3 \\
\hline 30 & 7 \\
\hline 31 & 3 \\
\hline 32 & 1 \\
\hline 33 & 2 \\
\hline 34 & 0 \\
\hline 35 & 1 \\
\hline 36 & 1 \\
\hline Table 1. CAN Score distribution of Foetally Malnourished \\
\multicolumn{2}{|c|}{ Babies } \\
\hline
\end{tabular}

\begin{tabular}{|c|c|}
\hline Total No. of Babies & $\mathbf{1 2 5}$ \\
\hline Total No. of AFD babies (\%) & $94(75.2 \%)$ \\
\hline Total No. SFD babies (\%) & $31(24.8 \%)$ \\
\hline \multicolumn{2}{|c|}{ Table 2 } \\
\hline
\end{tabular}

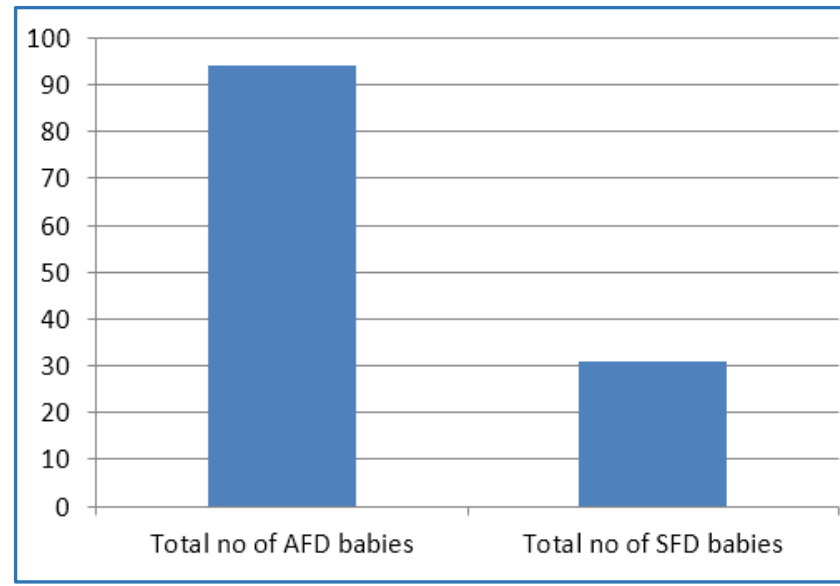

Graph 1

All the 125 babies were grouped into AFD and SFD using the growth percentile charts as shown in Table No. 2 and Graph No. 1 above. Out of 125 babies, 94 babies $(75,2 \%)$ were AFD babies and 31 babies (24.8\%) were SFD babies. Foetal malnutrition was assessed in both the groups with CAN Score cut-off's of $\leq 24$ and $\leq 21$. These are represented in the Charts No. 1 and 2 respectively. 


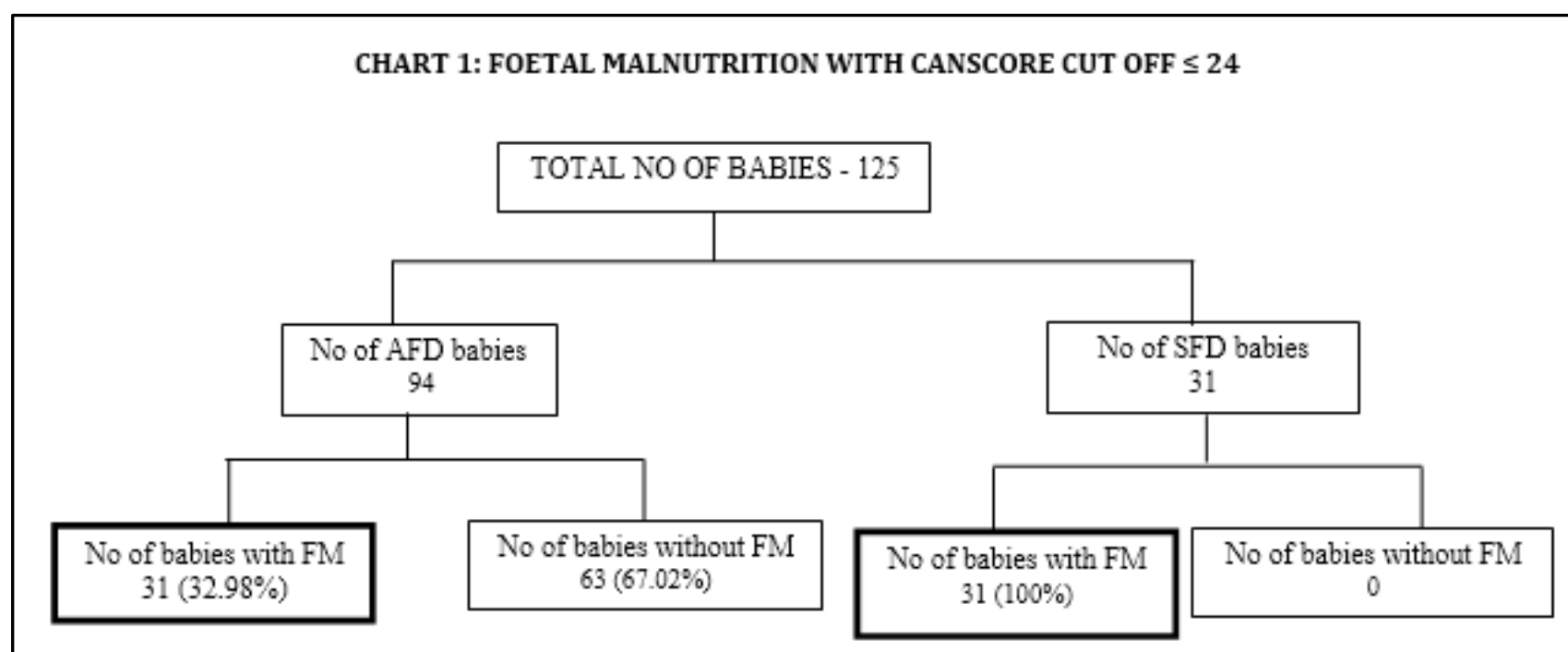

CHART 2: FOETAL MALNUTRITION WITH CANSCORE CUT OFF $\leq \mathbf{2 1}$

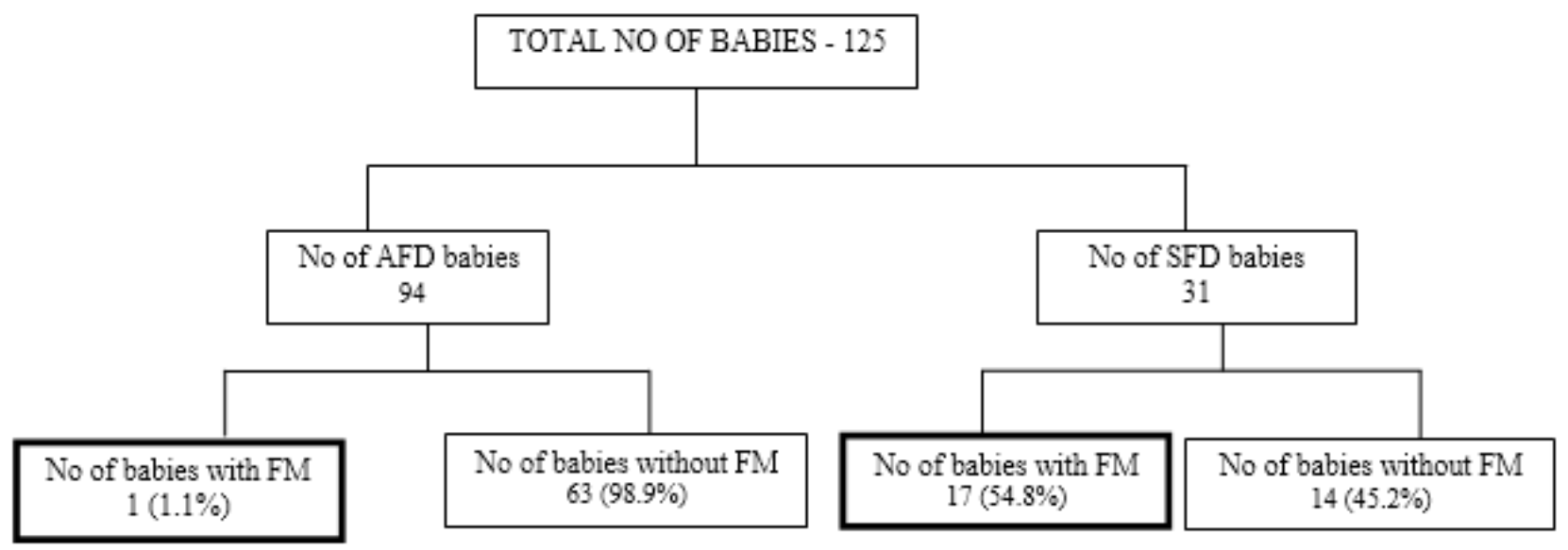

Out of 94 AFD babies, 31 babies (i.e. 32.98\%) were found to have foetal malnourishment with a CAN Score cut-off of $\leq 24$. All the 31 SFD babies $(100 \%)$ were also having foetal malnourishment with the same CAN score cut-off of $\leq 24$. But when CAN Score cut-off $\leq 21$ was considered, only 1 AFD baby $(1.1 \%)$ and 17 SFD babies $(54.8 \%)$ were found to be foetally malnourished.

Therefore, our target group includes a total of $62 \mathrm{FM}$ babies $(31+31)$ at CAN Score cut-off of $\leq 24$ and $18 \mathrm{FM}$ babies $(1+17)$ at CAN Score cut-off of $\leq 21$.

The association between the Foetal Malnutrition for the above babies and each factor of maternal data is checked with both CAN Score cut-off points at $\leq 24$ and $\leq 21$. All these are represented in Table No. 3 (3A to $3 \mathrm{~K}$ ).

Table 3. Contingency Tables with CAN Score cut-off points $a t \leq 24$ and $\leq 21$ and Maternal Factors

\begin{tabular}{|c|c|c|c|c|c|}
\hline $\begin{array}{c}\text { CAN Score } \\
\text { Cut-Off }\end{array}$ & Age & $\begin{array}{c}\text { Total } \\
\text { No. }\end{array}$ & $\begin{array}{c}\text { Total No. of } \\
\text { FM }\end{array}$ & \% & P value \\
\hline \multirow{2}{*}{24} & $\leq 20$ yrs. & 45 & 25 & $55.56 \%$ & $>0.05$ \\
\cline { 2 - 5 } & $>20$ yrs. & 80 & 37 & $46.25 \%$ & $(\mathrm{NS})$ \\
\hline \multirow{2}{*}{21} & $\leq 20$ yrs. & 45 & 4 & $8.9 \%$ & $>0.05$ \\
\cline { 2 - 5 } & $>20$ yrs. & 80 & 14 & $17.5 \%$ & $(\mathrm{NS})$ \\
\hline \multicolumn{6}{|c|}{ Table 3A. Association with maternal age at CAN Score cut- } \\
off of $\leq 24$ and $\leq \mathbf{2 1}$ \\
\hline
\end{tabular}

\begin{tabular}{|c|c|c|c|c|c|}
\hline $\begin{array}{c}\text { CAN Score } \\
\text { Cut-Off }\end{array}$ & Parity & $\begin{array}{c}\text { Total } \\
\text { No. }\end{array}$ & $\begin{array}{c}\text { Total } \\
\text { No. of FM }\end{array}$ & \% & P value \\
\hline \multirow{2}{*}{24} & Primi & 44 & 28 & $63.64 \%$ & $<0.05$ \\
\cline { 2 - 5 } & Multi & 81 & 34 & $41.98 \%$ & $(S)$ \\
\hline \multirow{2}{*}{21} & Primi & 44 & 9 & $20.45 \%$ & $>0.05$ \\
\cline { 2 - 5 } & Multi & 81 & 9 & $11.11 \%$ & (NS) \\
\hline
\end{tabular}

Table 3B. Association with Parity at CAN Score cut-off of < 24 and $<21$

\begin{tabular}{|c|c|c|c|c|c|}
\hline $\begin{array}{c}\text { CAN Score } \\
\text { Cut-Off }\end{array}$ & ANC & $\begin{array}{c}\text { Total } \\
\text { No. }\end{array}$ & $\begin{array}{c}\text { Total No. } \\
\text { of FM }\end{array}$ & \% & \multirow{2}{*}{ P value } \\
\hline \multirow{2}{*}{24} & $\geq 4$ visits & 99 & 47 & $47.5 \%$ & $>0.05$ \\
\cline { 2 - 5 } & $<4$ visits & 26 & 15 & $57.7 \%$ & $(\mathrm{NS})$ \\
\hline \multirow{2}{*}{21} & $\geq 4$ visits & 99 & 13 & $13.13 \%$ & $>0.05$ \\
\cline { 2 - 5 } & $<4$ visits & 26 & 5 & $19.23 \%$ & $(\mathrm{NS})$ \\
\hline
\end{tabular}

Table 3C. Association with Antenatal Check-Up at CAN Score cut-off of $\leq 24$ and $\leq 21$

\begin{tabular}{|c|c|c|c|c|c|}
\hline $\begin{array}{c}\text { CAN Score } \\
\text { Cut-Off }\end{array}$ & Diseases & $\begin{array}{c}\text { Total } \\
\text { No. }\end{array}$ & $\begin{array}{c}\text { Total No. } \\
\text { of FM }\end{array}$ & \% & P value \\
\hline \multirow{2}{*}{24} & Present & 15 & 7 & $46.67 \%$ & $>0.05$ \\
\cline { 2 - 5 } & Absent & 110 & 55 & $50 \%$ & $(\mathrm{NS})$ \\
\hline \multirow{2}{*}{21} & Present & 15 & 4 & $26.67 \%$ & $>0.05$ \\
\cline { 2 - 5 } & Absent & 110 & 14 & $12.72 \%$ & (NS) \\
\hline
\end{tabular}

Table 3D. Association with Diseases or Problems during Pregnancy at CAN Score cut-off of $\leq 24$ and $\leq 21$ 


\begin{tabular}{|c|c|c|c|c|c|}
\hline $\begin{array}{c}\text { CAN Score } \\
\text { Cut-Off }\end{array}$ & $\begin{array}{c}\text { Mode of } \\
\text { Delivery }\end{array}$ & Total No. & $\begin{array}{c}\text { Total } \\
\text { No. of } \\
\text { FM }\end{array}$ & \% & $\begin{array}{c}\text { P } \\
\text { value }\end{array}$ \\
\hline \multirow{2}{*}{24} & Normal & 112 & 59 & $52.68 \%$ & $<0.05$ \\
\cline { 2 - 5 } & LSCS & 13 & 3 & $23.08 \%$ & $($ NS) \\
\hline \multirow{2}{*}{21} & Normal & 112 & 18 & $16.07 \%$ & $>0.05$ \\
\cline { 2 - 6 } & LSCS & 13 & 0 & 0 & (NS) \\
\hline
\end{tabular}

Table 3E. Association with Mode of Delivery at CAN Score cut-off of $\leq 24$ and $\leq 21$

\begin{tabular}{|c|c|c|c|c|c|}
\hline $\begin{array}{c}\text { CAN Score } \\
\text { Cut-Off }\end{array}$ & Income & $\begin{array}{c}\text { Total } \\
\text { No. }\end{array}$ & $\begin{array}{c}\text { Total No. of } \\
\text { FM }\end{array}$ & $\mathbf{\%}$ & P value \\
\hline \multirow{2}{*}{24} & $<300 /-$ & 45 & 24 & $53.3 \%$ & $>0.05$ \\
\cline { 2 - 5 } & $>300 /-$ & 80 & 38 & $47.5 \%$ & $(\mathrm{NS})$ \\
\hline \multirow{2}{*}{21} & $<300 /-$ & 45 & 7 & $15.56 \%$ & $>0.05$ \\
& $>300 /-$ & 80 & 11 & $13.75 \%$ & $(\mathrm{NS})$ \\
\hline
\end{tabular}

Table 3F. Association with Socio-Economic Status at CAN Score cut-off of $\leq 24$ and $\leq 21$

\begin{tabular}{|c|c|c|c|c|c|}
\hline $\begin{array}{c}\text { CAN Score } \\
\text { Cut-Off }\end{array}$ & Literacy & $\begin{array}{c}\text { Total } \\
\text { No. }\end{array}$ & $\begin{array}{c}\text { Total No. } \\
\text { of FM }\end{array}$ & $\%$ & P value \\
\hline \multirow{4}{*}{24} & Illiterate & 52 & 25 & $46.15 \%$ & \multirow{4}{*}{$\begin{array}{c}>0.05 \\
(\mathrm{NS})\end{array}$} \\
\hline & $5^{\text {th }}$ class & 30 & 13 & $43.33 \%$ & \\
\hline & $6^{\text {th }}-10^{\text {th }}$ & 37 & 21 & $54.05 \%$ & \\
\hline & College & 6 & 3 & $50 \%$ & \\
\hline \multirow{4}{*}{21} & Illiterate & 52 & 7 & $13.46 \%$ & \multirow{4}{*}{$\begin{array}{c}>0.05 \\
(\mathrm{NS})\end{array}$} \\
\hline & $5^{\text {th }}$ class & 60 & 4 & $13.33 \%$ & \\
\hline & $6^{\text {th }}-10^{\text {th }}$ & 37 & 6 & $16.21 \%$ & \\
\hline & College & 6 & 1 & $16.67 \%$ & \\
\hline
\end{tabular}

Table 3G. Association with Literacy of the Mother at CAN Score cut-off of $\leq 24$ and $\leq 21$

\begin{tabular}{|c|c|c|c|c|c|}
\hline $\begin{array}{c}\text { CAN Score } \\
\text { Cut-Off }\end{array}$ & Spacing & $\begin{array}{c}\text { Total } \\
\text { No. }\end{array}$ & $\begin{array}{c}\text { Total No. } \\
\text { of FM }\end{array}$ & \% & P value \\
\hline & & & & & \\
\hline \multirow{2}{*}{24} & $<2$ Yrs. & 14 & 5 & $35.7 \%$ & $>0.05$ \\
& $\geq 2$ Yrs. & 67 & 29 & $43.28 \%$ & $(\mathrm{NS})$ \\
\hline \multirow{2}{*}{21} & $<2$ Yrs. & 14 & 3 & $21.43 \%$ & $>0.05$ \\
\cline { 2 - 5 } & $\geq 2$ Yrs. & 67 & 6 & $8.95 \%$ & $(\mathrm{NS})$ \\
\hline \multicolumn{7}{|c|}{ Table 3H. Association with Birth Spacing at CAN Score cut- } \\
off of $\leq 24$ and $\leq \mathbf{2 1}$ \\
\hline
\end{tabular}

Note: 44 mothers were primi gravida. Hence, spacing does not apply.

\begin{tabular}{|c|c|c|c|c|c|}
\hline $\begin{array}{c}\text { CAN Score } \\
\text { Cut-Off }\end{array}$ & $\mathbf{H b} \%$ & $\begin{array}{c}\text { Total } \\
\text { No. }\end{array}$ & $\begin{array}{c}\text { Total No. } \\
\text { of FM }\end{array}$ & $\mathbf{\%}$ & \multirow{2}{*}{ P value } \\
\hline \multirow{2}{*}{24} & $<9 \mathrm{gm} \%$ & 15 & 11 & $73.33 \%$ & \multirow{2}{*}{$<0.05(\mathrm{~S})$} \\
\cline { 2 - 6 } & $>9 \mathrm{gm} \%$ & 110 & 51 & $46.36 \%$ & \multirow{2}{*}{21} \\
\cline { 2 - 5 } & $<9 \mathrm{gm} \%$ & 15 & 4 & $26.67 \%$ & $>0.05$ \\
& $>9 \mathrm{gm} \%$ & 110 & 14 & 12.72 & (NS) \\
\hline
\end{tabular}

Table 3I. Association with Mother's Haemoglobin at CAN Score cut-off of $\leq 24$ and $\leq 21$

\begin{tabular}{|c|c|c|c|c|}
\hline $\begin{array}{c}\text { CAN Score } \\
\text { Cut-Off }\end{array}$ & Weight & Total No. & $\begin{array}{c}\text { Total No. of } \\
\text { FM }\end{array}$ & $\%$ \\
\hline \multirow{2}{*}{24} & $<40 \mathrm{~kg}$ & 10 & 5 & $50 \%$ \\
\hline & $\geq 40 \mathrm{~kg}$ & 54 & 29 & $53.7 \%$ \\
\hline \multirow{2}{*}{21} & $<40 \mathrm{~kg}$ & 10 & 2 & $20 \%$ \\
\hline & $\geq 40 \mathrm{~kg}$ & 54 & 8 & $14.81 \%$ \\
\hline $\begin{array}{l}\text { able } \\
\text { Preg }\end{array}$ & ociatic & $b$ & I We & $\begin{array}{l}\text { before } \\
\leq 21\end{array}$ \\
\hline
\end{tabular}

\begin{tabular}{|c|c|c|c|c|}
\hline $\begin{array}{c}\text { CAN Score } \\
\text { Cut-Off }\end{array}$ & $\begin{array}{c}\text { Weight } \\
\text { Gain }\end{array}$ & $\begin{array}{c}\text { Total } \\
\text { No. }\end{array}$ & $\begin{array}{c}\text { Total } \\
\text { No. of FM }\end{array}$ & \% \\
\hline \multirow{2}{*}{24} & $<9 \mathrm{~kg}$ & 11 & 6 & $54.5 \%$ \\
\cline { 2 - 5 } & $\geq 9 \mathrm{~kg}$ & 13 & 6 & $46.15 \%$ \\
\hline \multirow{2}{*}{21} & $<9 \mathrm{~kg}$ & 11 & 2 & $18.18 \%$ \\
\cline { 2 - 5 } & $\geq 9 \mathrm{~kg}$ & 13 & 1 & $7.69 \%$ \\
\hline
\end{tabular}

Table 3K. Association with Mother's Weight Gain during Pregnancy at CAN Score cut-off of $\leq 24$ and $\leq 21$

$\%$ - Percentage, NS - Not Significant, S - Significant, FM Foetal malnutrition.

The Association between the Nutritional Status and each Factor of Maternal Data is checked with Chi-Square Test. The Test Results are as follows-

- The test revealed that there is a significant association of parity with FM of the baby, when CAN Score cut-off of $<24$ is taken. It shows that babies born to primi gravida mother are more prone to develop FM. But similar association was not seen when CAN Score cut-off of $\leq 21$ was taken.

- The test results also revealed that there is significant association of mode of delivery with FM of new-born babies. In the present study, it has been found that FM was more in babies born by spontaneous vaginal delivery of outlet forceps delivery than in babies born by LSCS. This association was seen significant when CAN Score cut-off of $\leq 24$ was taken, but similar association with CAN Score cut-off of $\leq 21$ was not seen.

- The test results also revealed that mother's haemoglobin status has a strong association with the nutritional status of the baby. Mother with haemoglobin of $<9$ gms $\%$ are more prone to develop FM babies. This association was seen only with CAN Score cut-off of $\leq 24$, but not with cut-off score of $\leq 21$.

- The study results revealed that there is no association of other maternal factors like age of the mother, ANC, diseases during pregnancy, socio-economic status and literacy of the mother, birth spacing and maternal height with that of foetal malnutrition of the babies.

\section{DISCUSSION}

In the present study, maternal factors and the foetal malnutrition was correlated with both cut-off scores of $\leq 24$ and $\leq 21$. In the present study, it is noted that there is significant association of maternal haemoglobin concentration with the nutritional status of new born which reflects chronic maternal malnutrition. This is in contrast with Usher and Scott study. The present study shows that there is a strong association between the parity and nutritional status, which is in correlation with Scott and Usher study.

\begin{tabular}{|c|c|c|c|c|}
\hline & $\begin{array}{c}\text { J. Metcoff } \\
\text { Study }^{3}\end{array}$ & $\begin{array}{c}\text { Scott and } \\
\text { Usher }^{9}\end{array}$ & $\begin{array}{c}\text { Hill } \\
\text { et al10 }\end{array}$ & $\begin{array}{c}\text { Present } \\
\text { Study }\end{array}$ \\
\hline $\begin{array}{c}\text { Total } \\
\text { Incidence } \\
\text { of FM }\end{array}$ & $10.9 \%$ & $10 \%$ & $54.5 \%$ & $49.6 \%$ \\
\hline $\begin{array}{c}\text { Association } \\
\text { with } \\
\text { Maternal } \\
\text { Factors }\end{array}$ & -- & $\begin{array}{c}\text { Primi parity } \\
\text { irregular ANC } \\
\text { Low Maternal } \\
\text { Wt. }\end{array}$ & $\begin{array}{c}\text { No } \\
\text { association }\end{array}$ & $\begin{array}{c}\text { HB\%, Primi } \\
\text { parity, } \\
\text { mode of } \\
\text { delivery }\end{array}$ \\
\hline \multicolumn{2}{|c|}{ Table }
\end{tabular}


When age of the mothers was taken into consideration, it was not a factor of influence on the foetus for foetal malnutrition with both cut-off scores of $\leq 24$ and $\leq 21$.

When parity was taken into account, it was found that $63.64 \%$ of babies born to primi para mothers and $41.98 \%$ of babies born to multi gravida were having foetal malnutrition with CAN Score cut-off at $\leq 24$. Scott and Usher study ${ }^{11}$ had similar results showing foetal malnutrition associated with primi parity. However, when the cut-off score was decreased to $\leq 21$, the association of parity and foetal malnutrition was not observed in the present study.

The number of antenatal check-ups of the mother during her pregnancy period did not have any influence in the malnutrition of foetus when the cut-off CAN Score was $\leq 24$ in our study. However, irregular antenatal check-ups had an effect on the nutritional status of the growing foetus in the study conducted by Scott and Usher. 11

$52.68 \%$ of the babies born through vaginal route were found to have malnourishment when CAN Score cut-off was $\leq 24$ compared to only $23.08 \%$ of babies born through LSCS which was statistically significant in our study. The same was not recorded in other studies conducted by Hill et $\mathrm{al}^{10}$ and Scott and Usher ${ }^{11}$ studies.

Maternal haemoglobin level was of much influential factor in our study causing foetal malnutrition. $73.33 \%$ of the babies were born malnourished when the mother's haemoglobin concentration was less than $9 \mathrm{gm} \%$. The p-value was statistically significant with less than 0.05 . However, this association of maternal haemoglobin and foetal malnutrition was noted with CAN Score cut-off of $\leq 24$, but not with cut-off score of $\leq 21$ in this study. Other studies did not show similar kind of results.

Low maternal weight gain was noted to have influence on the nutritional status of the foetus. This was found in the study conducted by Scott and Usher. In our study, this association was not seen.

Other factors like birth spacing, diseases or problems in pregnancy, literacy of the mothers and mother's height did not show any association with foetal malnutrition either with CAN Score cut-off of $<24$ or $<21$ in our study.

The association between FM and factors like drug intake during pregnancy and maternal habits could not be made, because in this sample not even a single mother has received any drug or has any habits or addictions. However, we think it is important to mention is this discussion that some studies have shown that some mothers who smoked during pregnancy, but received nutritional supplementation from mid-pregnancy period had babies who were significantly heavier than babies of smokers who were not supplemented.

\section{CONCLUSION}

Factors affecting the maternal health play a crucial role in influencing foetal growth and birth outcomes. Maternal health is of public health importance in an effort to prevent adverse birth outcomes, particularly among the population in developing countries like India. Based on the findings of the present study, it can be concluded that pregnant women who had low-levels of haemoglobin had an adverse birth outcome affecting the foetal growth and was the cause of foetal malnutrition. Hence, nutrition intervention and iron and folate supplementation should be given for the community, particularly for the pregnant mothers.

The other identified maternal factors associated with foetal malnutrition were primi parity and mode of delivery in our study. Maternal factors that were not significantly associated with foetal malnutrition were smoking, socioeconomic status, maternal age and number of school years completed.

Hence, in order to reduce the adverse pregnancy outcomes, awareness should be created among pregnant women and women of child bearing age about the factors that can improve the nutritional status of the women prior to conception and during pregnancy.

\section{REFERENCES}

[1] Oluwafemi RO, Njokanma OF, Disu EA, et al. Maternal factors in the aetiology of small-for-gestational age among term Nigerian babies. Niger J Paed 2013;40(2):119-24.

[2] Singh M. Care of newborn. $6^{\text {th }}$ edn. New Delhi, Sagar Publications, 2004.

[3] Metcoff J. Clinical assessment of nutritional status at birth. Fetal malnutrition and SGA are not synonymous. Pediatr Clin North Am 1994;41(5):875-91.

[4] Barker DJ, Gluckman PD, Godfrey KM, et al. Fetal nutrition and cardiovascular disease in adult life. Lancet 1993;341(8850):938-41.

[5] Low birth weight: Country, regional and global estimates. New York: UNICEF; United Nations Children's Fund and World Health Organization, 2004.

[6] Kumar PU, Ramalaxmi BA, Venkiah K, et al. Effect of maternal under nutrition on human foetal pancreas morphology in second trimester of pregnancy. Indian J Med Res 2013;137(2):302-7.

[7] Alizadeh L, Raoofi A, Salehi L, et al. Impact of maternal hemoglobin concentration on fetal outcomes in adolescent pregnant women. Iran Red Crescent Med J 2014;16(8):e19670.

[8] Steer PJ. Maternal hemoglobin concentration and birth weight. Am J Clin Nutr 2000;71(5 Suppl):1285S-7S.

[9] Varahala AM, Chidugulla SK, Pathuri NK. Assessment of foetal malnutrition by CANSCORE and comparison with anthropometric attributes-a tertiary care centre experience. IOSR Journal of Dental and Medical Sciences 2015;14(10):07-12.

[10] Hill RM, Verniaud WM, Deter RL, et al. The effect of intrauterine malnutrition on the term infant. A 14year progressive study. Acta Paediatr Scand 1984;73(4):482-7.

[11] Scott KE, Usher R. Fetal malnutrition: its incidence, causes and effects. Am J Obstet Gynaecol 1966;94(7):951-63. 